Check for updates

Cite this: RSC Adv., 2017, 7, 21585

Received 22nd February 2017

Accepted 3rd April 2017

DOI: 10.1039/c7ra02201h

rsc.li/rsc-advances

\section{Computational assessment of nitrogen-rich peracids: a family of peroxide-based energetic materials $\uparrow$}

\begin{abstract}
Papiya Parbat, Alka Devi and Vikas D. Ghule (D)*
Nitrogen-rich 5- and 6-membered compounds substituted with nitro and peracid groups were designed and investigated using density functional theory (DFT). The calculated energetic properties of peracid compounds were compared with those of some classical explosives such as TNT and RDX. The computed results show that most of the designed peracids possess large positive heats of formation (HOF) and much higher densities $\left(1.79-1.89 \mathrm{~g} \mathrm{~cm}^{-3}\right)$. The predicted detonation properties impart performance superior to that of TNT and comparable to that of RDX. The relatively better oxygen balance results in higher heat of detonation and more gaseous combustion products. Based on the predicted energetic properties of the designed compounds, the present study emphasizes the potential of the peracid group in developing new energetic materials.
\end{abstract}

\section{Introduction}

The search and development of energetic materials with tunable properties is an unalterable goal for researchers working in this field as these materials belong to the class of hazardous materials. The importance of energetic materials in the civil and military field has led to significant growth in environmentally friendly compounds in recent years. ${ }^{1-9}$ Furthermore, designing a new compound and estimating its energetic properties is a typical practice before synthesis to reduce the cost and associated hazardous effects. ${ }^{10-13}$ Covalent peroxides $(\mathrm{O}-\mathrm{O})$ are classified as peracid $(\mathrm{RC}(\mathrm{O}) \mathrm{OOH})$, perester $\left(\mathrm{RC}(\mathrm{O}) \mathrm{OOR}^{\prime}\right)$, perether $\left(\mathrm{ROOR}^{\prime}\right)$, and peracetal $\left(\mathrm{ROOR}^{\prime} \mathrm{OOR}\right)$ compounds. ${ }^{14}$ TATP (triacetone triperoxide) and HMTD (hexamethylene triperoxide diamine) are known compounds of peroxide explosives containing three $-\mathrm{O}-\mathrm{O}-$ linkages per molecule (see Fig. S1 in the ESI $\dagger$ ). They are highly sensitive and brisant in nature, and their blast strength has been reported to be $88 \%$ and $60 \%$ that of TNT and RDX, respectively. In this study, we focused on the design of peracid $(\mathrm{RC}(\mathrm{O}) \mathrm{OOH})$ groupcontaining explosives, which have not been widely explored. In recent studies, Klapötke et al. ${ }^{15,16}$ have reported peroxidecontaining explosives with reasonable sensitivity and performance and suggested the incorporation of peroxide-containing functional groups to improve the oxygen balance. Since peracid group has more oxygen atoms, it is expected that this would help in the rapid self-decomposition of a compound. In this

Department of Chemistry, National Institute of Technology, Kurukshetra-136119, Haryana, India.E-mail: gvd@nitkkr.ac.in

$\dagger$ Electronic supplementary information (ESI) available. See DOI: $10.1039 / \mathrm{c} 7 \mathrm{ra} 02201 \mathrm{~h}$ study, we selected nitrogen-rich backbones that have been reported in the literature ${ }^{1,17-22}$ and introduced the peracid group along with the nitro group. Herein, nitrogen-rich peracids have been described as promising energetic materials and potential propellants. Theoretical methods and correlations were used to investigate their electronic structure, heat of formation (HOF), density, performance properties, and sensitivity. We believe that our theoretical studies of peracid compounds will aid further investigations in the incorporation of peracid functionalities in energetic materials.

\section{Results and discussion}

Fig. 1 lists the molecular structures of the designed nitrogenrich peracid compounds. For each of these, we optimized the structures and computed the surface properties at the B3PW91/ 6-31G (d,p) level using the Gaussian 09 (ref. 23) and Multiwfn program. ${ }^{24}$ All of the optimized peracid structures were characterized to be true local energy minima on their potential energy surfaces without imaginary frequencies. The computational methodology used for the calculation of energetic properties is similar to that reported in our earlier studies ${ }^{25-29}$ and has been illustrated in the ESI. $\dagger$ The nitro compounds P4, P6, P10, P13, P16, P19, P25, and $\mathbf{P 2 8}$ have been reported in the literature $^{30-39}$ and their energetic properties were compared with those of the designed peracid analogues.

\section{Heat of formation}

The heat of formation (HOF) is an important thermochemical property for an explosive, and it plays a significant role in the prediction of the heat of explosion, heat of combustion, and 
<smiles>[Y]c1n[nH]c([Y])n1</smiles>

P1: $\mathrm{R}^{1}=\mathrm{C}(\mathrm{O}) \mathrm{OOH}, \mathrm{R}^{2}=\mathrm{H}$

P2: $\mathrm{R}^{1}=\mathrm{C}(\mathrm{O}) \mathrm{OOH}, \mathrm{R}^{2}=\mathrm{NO}_{2}$ P3: $\mathrm{R}^{1}=\mathrm{NO}_{2}, \mathrm{R}^{2}=\mathrm{H}$

P4: $\mathrm{R}^{1}=\mathrm{R}^{2}=\mathrm{NO}_{2}$<smiles>[Y]c1nnc([Y])nn1</smiles>

P11: $\mathrm{R}^{1}=\mathrm{R}^{2}=\mathrm{C}(\mathrm{O}) \mathrm{OOH}$ P12: $\mathrm{R}^{1}=\mathrm{C}(\mathrm{O}) \mathrm{OOH}, \mathrm{R}^{2}=\mathrm{NO}_{2}$ P13: $\mathrm{R}^{1}=\mathrm{R}^{2}=\mathrm{NO}_{2}$

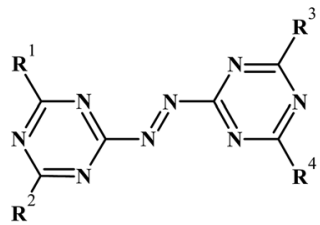

P20: $\mathrm{R}^{1}=\mathrm{R}^{2}=\mathrm{R}^{3}=\mathrm{R}^{4}=\mathrm{C}(\mathrm{O}) \mathrm{OOH}$

P21: $R^{1}=R^{2}=R^{3}=C(O) O O H, R^{4}=N_{2}$

P22: $\mathrm{R}^{1}=\mathrm{R}^{2}=\mathrm{C}(\mathrm{O}) \mathrm{OOH}, \mathrm{R}^{3}=\mathrm{R}^{4}=\mathrm{NO}_{2}$

P23: $\mathrm{R}^{1}=\mathrm{R}^{3}=\mathrm{C}(\mathrm{O}) \mathrm{OOH}, \mathrm{R}^{2}=\mathrm{R}^{4}=\mathrm{NO}_{2}$

P24: $\mathrm{R}^{1}=\mathrm{C}(\mathrm{O}) \mathrm{OOH}, \mathrm{R}^{2}=\mathrm{R}^{3}=\mathrm{R}^{4}=\mathrm{NO}_{2}$

P25: $\mathrm{R}^{1}=\mathrm{R}^{2}=\mathrm{R}^{3}=\mathrm{R}^{4}=\mathrm{NO}_{2}$<smiles>c1nnn[nH]1</smiles>

P5: $\mathrm{R}=\mathrm{C}(\mathrm{O}) \mathrm{OOH}$ P6: $\mathrm{R}=\mathrm{NO}_{2}$<smiles>[Y]c1nc([Y])nc([Y])n1</smiles>

P7: $\mathrm{R}^{1}=\mathrm{R}^{2}=\mathrm{R}^{3}=\mathrm{C}(\mathrm{O}) \mathrm{OOH}$

P8: $\mathrm{R}^{1}=\mathrm{R}^{2}=\mathrm{C}(\mathrm{O}) \mathrm{OOH}, \mathrm{R}^{3}=\mathrm{NO}_{2}$ P9: $\mathrm{R}^{1}=\mathrm{C}(\mathrm{O}) \mathrm{OOH}, \mathrm{R}^{2}=\mathrm{R}^{3}=\mathrm{NO}_{2}$ P10: $\mathrm{R}^{1}=\mathrm{R}^{2}=\mathrm{R}^{3}=\mathrm{NO}_{2}$<smiles>[R]c1n[nH]c(N=Nc2nc([R])n[nH]2)n1</smiles>

P14: $\mathrm{R}^{1}=\mathrm{R}^{2}=\mathrm{C}(\mathrm{O}) \mathrm{OOH}$ P15: $\mathrm{R}^{1}=\mathrm{C}(\mathrm{O}) \mathrm{OOH}, \mathrm{R}^{2}=\mathrm{NO}_{2}$ P16: $\mathrm{R}^{1}=\mathrm{R}^{2}=\mathrm{NO}_{2}$<smiles>[3H]c1nnnn1/C=N/n1nnnc1P</smiles>

P17: $\mathrm{R}^{1}=\mathrm{R}^{2}=\mathrm{C}(\mathrm{O}) \mathrm{OOH}$ P18: $\mathrm{R}^{1}=\mathrm{C}(\mathrm{O}) \mathrm{OOH}, \mathrm{R}^{2}=\mathrm{NO}_{2}$ P19: $\mathrm{R}^{1}=\mathrm{R}^{2}=\mathrm{NO}_{2}$

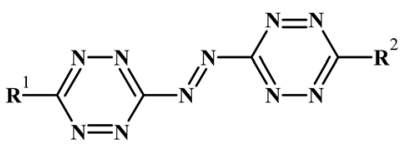

P26: $\mathrm{R}^{1}=\mathrm{R}^{2}=\mathrm{C}(\mathrm{O}) \mathrm{OOH}$

P27: $\mathrm{R}^{1}=\mathrm{C}(\mathrm{O}) \mathrm{OOH}, \mathrm{R}^{2}=\mathrm{NO}_{2}$ P28: $\mathrm{R}^{1}=\mathrm{R}^{2}=\mathrm{NO}_{2}$

Fig. 1 Molecular structures of the peracid compounds.

other performance parameters. In the present study, $\mathrm{HOF}_{\text {gas }}$ was predicted using an isodesmic reaction approach with single point energies calculated at the B3PW91/6-31G(d,p) level. Detailed information of the designed isodesmic reactions, carried out to obtain $\mathrm{HOF}_{\text {gas }}$ of peracid derivatives, has been provided in the ESI (Fig. S2 $\dagger$ ). $\mathrm{HOF}_{\text {solid }}$ for all the peracid derivatives were obtained by subtracting the heat of sublimation $\left(\mathrm{HOF}_{\text {sub }}\right)$ from $\mathrm{HOF}_{\text {gas }}$, according to the Politzer approach. Table 1 summarizes the calculated oxygen balance, nitrogen content, $\mathrm{HOF}_{\text {gas }}, \mathrm{HOF}_{\text {sub }}$, and $\mathrm{HOF}_{\text {solid }}$ of the peracid derivatives. It was observed that the calculated $\mathrm{HOF}_{\text {gas }}$ of P6, P13, P19, and $\mathbf{P 2 5}$ are close to the reported values, indicating that our calculated results are reliable. Compared with other nitrogenrich peracid derivatives, $\mathbf{P 2 7}$ has an extremely high $\mathrm{HOF}_{\text {solid }}$ of $867 \mathrm{~kJ} \mathrm{~mol}^{-1}$, may stem from the rich $\mathrm{N}-\mathrm{N}$ and $\mathrm{C}-\mathrm{N}$ bonds of the s-tetrazine ring and azo bond in the compound. All the peracid substituted derivatives possess lower $\mathrm{HOF}_{\text {solid }}$ when compared to the corresponding nitro derivatives, indicating that the peracid groups decrease the HOF. We observed that the peracid group was unfavourable for increasing the HOF, resulting in the negative values. All the designed peracid derivatives possess negative $\mathrm{HOF}_{\text {solid }}$ except for P12, P15, P17, P18, P24, P26, and P27. Among P14-15 and P17-18, HOF $_{\text {solid }}$ of the compounds P17-18 were greater, owing to higher energy contribution from the tetrazole rings. This may be due to difference in the HOFs of triazine and tetrazine peracid derivatives.

\section{Density and oxygen balance}

Density is an essential physical parameter to calculate the detonation performance of an energetic material. ${ }^{40-43} \mathrm{~A}$ higher density value also ensures the packing of more material per unit volume, thereby results in a greater explosion. The densities of the peracid derivatives were predicted using the Politzer et al. ${ }^{44}$ approach (Table 1) and was found in the range of $1.79-1.88 \mathrm{~g} \mathrm{~cm}^{-3}$, which were much higher than those of TNT $\left(1.65 \mathrm{~g} \mathrm{~cm}^{-3}\right)$ and comparable to those of RDX $(1.80 \mathrm{~g}$ $\mathrm{cm}^{-3}$ ). Note that replacement of peracid group by nitro does not show a significant change in the density. However, nitro group has a slight advantage over peracid functionality in terms of improved density. The hydrogen atoms in peracid groups and $\mathrm{N}-\mathrm{H}$ of the azole rings may help in building strong inter- and intra-molecular hydrogen bond network, thereby contributing in improving the density at the same time. It was observed that densities of triazine peracid derivatives (P7-9 and P20-24) were higher than those of tetrazine peracid derivatives (P11-12 and P26-27). This could be attributed to the substitution of peracid and nitro groups in triazine derivatives. Along with density, oxygen balance (OB) is also an essential parameter that indicates the index of oxygen in a compound required to convert all the carbon and hydrogen atoms into $\mathrm{CO}_{2}$ and $\mathrm{H}_{2} \mathrm{O}$, respectively, releasing most of the energy. The designed peracids have a nitrogen-rich backbone, 
Table 1 Calculated oxygen balance (OB, \%), nitrogen content (NC, \%), density $\left(\rho, \mathrm{g} \mathrm{cm}^{-3}\right)$, heat of formation in gas phase $\left(\mathrm{HOF}_{\text {gas }}, \mathrm{kJ}\right.$ mol $\left.{ }^{-1}\right)$ and solid phase $\left(\mathrm{HOF}_{\text {solid, }} \mathrm{kJ} \mathrm{mol}^{-1}\right)$, and heat of sublimation $\left(\mathrm{HOF}_{\mathrm{sub}}, \mathrm{kJ} \mathrm{mol}^{-1}\right)$ of the peracid compounds ${ }^{a}$

\begin{tabular}{|c|c|c|c|c|c|c|}
\hline P1 & -56 & 33 & 1.79 & -80 & 99 & -179 \\
\hline P3 & -42 & 49 & 1.80 & 192 & 92 & 100 \\
\hline $\mathbf{P 4}$ & -05 & 44 & 1.87 & 204 & 88 & 116 \\
\hline P5 & -25 & 43 & 1.82 & 58 & 90 & -32 \\
\hline P8 & -20 & 23 & 1.86 & -270 & 126 & -396 \\
\hline P9 & -10 & 30 & 1.88 & -4 & 108 & -112 \\
\hline P10 & 00 & 39 & 1.89 & 265 & 92 & 173 \\
\hline P11 & -24 & 28 & 1.83 & -11 & 103 & -114 \\
\hline P12 & -13 & 37 & 1.84 & 260 & 86 & 174 \\
\hline P13 & 00 & 49 & 1.85 & $534(533)^{34}$ & 70 & 464 \\
\hline P18 & -09 & 57 & 1.84 & 934 & 140 & 794 \\
\hline P19 & 00 & 66 & 1.85 & $1229(1186)^{37}$ & 123 & 1106 \\
\hline P20 & -37 & 26 & 1.80 & -289 & 303 & -592 \\
\hline P21 & -33 & 30 & 1.81 & -28 & 283 & -311 \\
\hline P22 & -28 & 35 & 1.82 & 239 & 261 & -22 \\
\hline $\mathbf{P 2 3}$ & -28 & 35 & 1.82 & 237 & 260 & -23 \\
\hline P24 & -23 & 40 & 1.83 & 506 & 239 & 267 \\
\hline P25 & -17 & 46 & 1.84 & $774(770)^{38}$ & 217 & 557 \\
\hline P26 & -36 & 45 & 1.80 & 762 & 184 & 578 \\
\hline P27 & -30 & 52 & 1.81 & 1032 & 165 & 867 \\
\hline P28 & -23 & 60 & 1.83 & 1304 & 147 & 1157 \\
\hline
\end{tabular}

which is beneficial to achieve better OB. Among the designed compounds, P10, P13, and P19 possess neutral oxygen balance, indicating that oxygen is sufficient for their complete combustion. Moreover, other compounds such as P2, P4, P6, P8, P9, P12, P17, P18, and P25 have good OB, better than those of RDX $(-21.6 \%)$ and HMX $(-21.6 \%)$. The deceased $\mathrm{C}-\mathrm{H}$ group in the backbone of the tetrazole peracid derivatives (P5, P17, and P18) helped to achieve better OB than that of the corresponding triazole derivatives (P1, P14, and P15). The high densities and OB were apparently ascribed to the high nitrogen content, and peracid and nitro groups in these compounds.

\section{Performance parameters}

Detonation velocity $(D)$, pressure $(P)$, heat of detonation $(Q)$, explosive power (EP), power index (PI), brisance, Gurney velocity $(\sqrt{2 E})$, and heat of combustion $\left(\Delta H_{\mathrm{c}}\right)$ are important measures of the performance of detonating explosives. All these performance parameters have been listed in Table 2 . Fig. 2 and 3 compare the energetic properties of the peracid compounds with those of TNT and RDX. The designed peracids have detonation velocities ranging from 7.14 (P1) to 8.96 $\mathrm{km} \mathrm{s}^{-1}$ (P18) and pressures were found in the range from 22.53 (P1) to 36.06 GPa (P18), which were higher than those of TNT
( $D=6.94 \mathrm{~km} \mathrm{~s}^{-1}$ and $\left.P=22.0 \mathrm{GPa}\right)$. The compounds $\mathbf{P 1 2}$ and P18 have $D$ and $P$ comparable with $\operatorname{RDX}\left(D=8.60 \mathrm{~km} \mathrm{~s}^{-1}\right.$ and $P$ $=33.92 \mathrm{GPa}$ ). Among these, $\mathbf{P 1 8}$ has the highest $D$ and $P$ of 8.96 $\mathrm{km} \mathrm{s}^{-1}$ and $36.06 \mathrm{GPa}$, respectively. It can be seen from Table 2 that all peracids show $Q$ values higher than $1100 \mathrm{cal} \mathrm{g}^{-1}$, except for P1, P7, P14, and P20. The $Q$ values of these compounds are comparable or higher than those of the common explosives TNT (1043 $\left.\mathrm{cal} \mathrm{g}^{-1}\right)$ and RDX (1138 $\left.\mathrm{cal} \mathrm{g}^{-1}\right)$. Power index (PI) is an important parameter to represent the strength of the explosives, and it depends on the volume of the gas liberated during the explosion and the heat of detonation. In peracid derivatives, $\mathbf{P 1 8}(170 \%)$ surpassed the power index of RDX (169\%) due to more volume of gaseous explosion products, whereas P2, P9, P11, P12, P17, P26, and P27 were found to be more powerful than TNT (116\%). Most of the designed peracids have negative $\mathrm{OB}$, eventually reducing the gaseous explosion products and performance. Detonation performance is also linked with brisance, and superior brisance indicates effectiveness of an explosion in the fragmentation of shells and casings. ${ }^{45}$ The estimated brisance values relative to that of TNT $(\sim 100)$ for peracid derivatives were found in the range from 96 to 142 . Compared to TNT, designed compounds exhibited higher brisance values (except for P1), whereas those of P18 and P24 were comparable with that of RDX (140). Gurney ${ }^{46}$ has derived a series of equations to 
Table 2 Calculated detonation velocity $\left(D, \mathrm{~km} \mathrm{~s}^{-1}\right)$, detonation pressure $(P, \mathrm{GPa})$, chemical energy of detonation $\left(Q\right.$, cal $\left.\mathrm{g}^{-1}\right)$, explosive power $\left(E P, k J ~ \mathrm{dm}^{3} \mathrm{~g}^{-2}\right)$, power index $(\mathrm{Pl}, \%)$, heat of combustion $\left(\Delta H_{\mathrm{c}}, \mathrm{cal} \mathrm{g}^{-1}\right)$, brisance, and Gurney velocity $(\sqrt{2 E}, \mathrm{~km} \mathrm{~s})$ of peracid compounds

\begin{tabular}{|c|c|c|c|c|c|c|c|c|c|}
\hline Compd & $\begin{array}{l}D \\
\left(\mathrm{~km} \mathrm{~s}^{-1}\right)\end{array}$ & $\begin{array}{l}P \\
(\mathrm{GPa})\end{array}$ & $\begin{array}{l}Q \\
\left(\mathrm{cal} \mathrm{g}^{-1}\right)\end{array}$ & $\begin{array}{l}\mathrm{EP} \\
\left(\mathrm{kJ} \mathrm{dm} \mathrm{dg}^{3} \mathrm{~g}^{-2}\right)\end{array}$ & $\begin{array}{l}\text { PI } \\
(\%)\end{array}$ & $\begin{array}{l}\Delta H_{\mathrm{c}} \\
\left(\mathrm{cal} \mathrm{g}^{-1}\right)\end{array}$ & Brisance & $\begin{array}{l}\text { K-F } \\
\text { method }^{a}\end{array}$ & $\begin{array}{l}\mathrm{H}-\mathrm{K} \\
\text { method }^{b}\end{array}$ \\
\hline P1 & 7.14 & 22.53 & 886 & 2111 & 78 & 2639 & 96 & 2.38 & 2.44 \\
\hline $\mathbf{P} 2$ & 8.15 & 29.97 & 1181 & 3304 & 122 & 1777 & 107 & 2.69 & 2.69 \\
\hline P3 & 7.84 & 27.28 & 1129 & 3118 & 115 & 2451 & 102 & 2.61 & 2.62 \\
\hline P6 & 8.90 & 35.72 & 1413 & 4315 & 160 & 1659 & 111 & 2.94 & 2.88 \\
\hline P7 & 7.66 & 26.45 & 1061 & 2279 & 84 & 1928 & 104 & 2.53 & 2.56 \\
\hline P8 & 8.02 & 29.06 & 1186 & 2850 & 106 & 1799 & 110 & 2.64 & 2.65 \\
\hline P9 & 8.44 & 32.40 & 1332 & 3403 & 126 & 1658 & 116 & 2.77 & 2.76 \\
\hline P10 & 8.87 & 35.89 & 1497 & 3900 & 144 & 1497 & 122 & 2.91 & 2.86 \\
\hline P11 & 8.16 & 29.80 & 1315 & 3274 & 121 & 2061 & 107 & 2.70 & 2.69 \\
\hline P16 & 8.18 & 30.07 & 1248 & 3344 & 124 & 2215 & 131 & 2.70 & 2.70 \\
\hline P17 & 8.57 & 32.91 & 1428 & 3971 & 147 & 1956 & 136 & 2.84 & 2.80 \\
\hline P18 & 8.96 & 36.06 & 1587 & 4586 & 170 & 1866 & 142 & 2.96 & 2.90 \\
\hline P19 & 9.38 & 39.63 & 1767 & 5178 & 192 & 1768 & 148 & 3.09 & 3.00 \\
\hline P20 & 7.38 & 24.17 & 1037 & 1940 & 72 & 2181 & 124 & 2.46 & 2.50 \\
\hline P21 & 7.60 & 25.70 & 1110 & 2331 & 86 & 2114 & 130 & 2.52 & 2.56 \\
\hline P22 & 7.83 & 27.40 & 1194 & 2740 & 101 & 2047 & 136 & 2.60 & 2.61 \\
\hline P23 & 7.83 & 27.40 & 1194 & 2737 & 101 & 2046 & 136 & 2.60 & 2.61 \\
\hline P24 & 8.08 & 29.25 & 1285 & 3144 & 116 & 1974 & 142 & 2.67 & 2.68 \\
\hline P25 & 8.34 & 31.27 & 1383 & 3541 & 131 & 1895 & 148 & 2.76 & 2.74 \\
\hline P26 & 8.08 & 28.98 & 1390 & 3513 & 130 & 2483 & 131 & 2.69 & 2.68 \\
\hline P27 & 8.39 & 31.33 & 1517 & 4007 & 148 & 2410 & 137 & 2.79 & 2.76 \\
\hline
\end{tabular}

${ }^{a}$ Kamlet-Finger method [ref. 47]. ${ }^{b}$ Hardesty-Kennedy method [ref. 48].

account the effectiveness of an explosive that will accelerate/ fragment the surrounding layer of metal or other material when detonated. Gurney velocity is a useful parameter to estimate the energy output of the detonating explosive. In the present study, we used the Kamlet-Finger method $^{47}$ to calculate Gurney velocity of designed peracid derivatives. To validate the consistency of Kamlet-Finger method, Gurney velocities were also calculated using the Hardesty-Kennedy method $^{48}$ (see Table 2). It was found that both these methods resulted in comparable values. From the computed $\sqrt{2 E}$ values (in Table 2), P18 (2.96 $\left.\mathrm{km} \mathrm{s}^{-1}\right)$ showed highest value among the peracids and RDX $\left(2.93 \mathrm{~km} \mathrm{~s}^{-1}\right)$ due to the higher kinetic energy of its explosion products. All the other designed peracids possess better $\sqrt{2 E}$ when compared to TNT $(2.37 \mathrm{~km}$ $\mathrm{s}^{-1}$ ), ranging from 2.38 to $2.96 \mathrm{~km} \mathrm{~s}^{-1}$. Overall, the designed peracids have performance parameters between TNT and RDX. $\Delta H_{\mathrm{c}}$ mainly depends on the composition of the molecule and are required to account the total combustion energy of explosives and decomposition products. The higher oxygen balance (OB) ensures the supply of oxygen during the explosion process and results in a large amount of gaseous combustion products. In the present study, $\Delta H_{\mathrm{c}}$ is predicted to account the heat released during the combustion and has been summarized in Table 2. $\Delta H_{\mathrm{c}}$ values were always higher than those of $Q$ as oxygen was supplied to the explosive and complete conversion of $\mathrm{C}$ and $\mathrm{H}$ atoms to $\mathrm{CO}_{2}$ and $\mathrm{H}_{2} \mathrm{O}$ occurred, respectively. The detonation products of the designed peracids have been listed in Table S4. $\dagger$ Among the designed peracids, P1, P14, P15, P26, and $\mathbf{P 2 7}$ possess superior $\Delta H_{\mathrm{c}}$ when compared to RDX $\left(2255 \mathrm{cal} \mathrm{g}^{-1}\right)$.

\section{Sensitivity correlations}

Along with higher detonation properties, the explosive candidate should be less sensitive towards external stimuli, concomitantly improving chances for practical application. Politzer et al. ${ }^{49}$ have suggested that the heat of detonation $(Q)$ can be used to assess the sensitivity of energetic materials and sensitivity of energetic material tend to increase as $Q$ becomes higher. The predicted $Q$ values have been listed in Table 2, and it can be seen that P2, P8-9, P11-12, P17-18, and P22-27 have higher $Q$ values in comparison to TNT (1044 $\mathrm{cal} \mathrm{g}^{-1}$ ) and RDX (1138 $\mathrm{cal} \mathrm{g}^{-1}$ ), indicating their sensitivity behavior. It was observed that replacement of peracid group with the nitro group increased the sensitivity of the resultant compounds. Therefore, adjusting the peracid and nitro groups in nitrogen- 


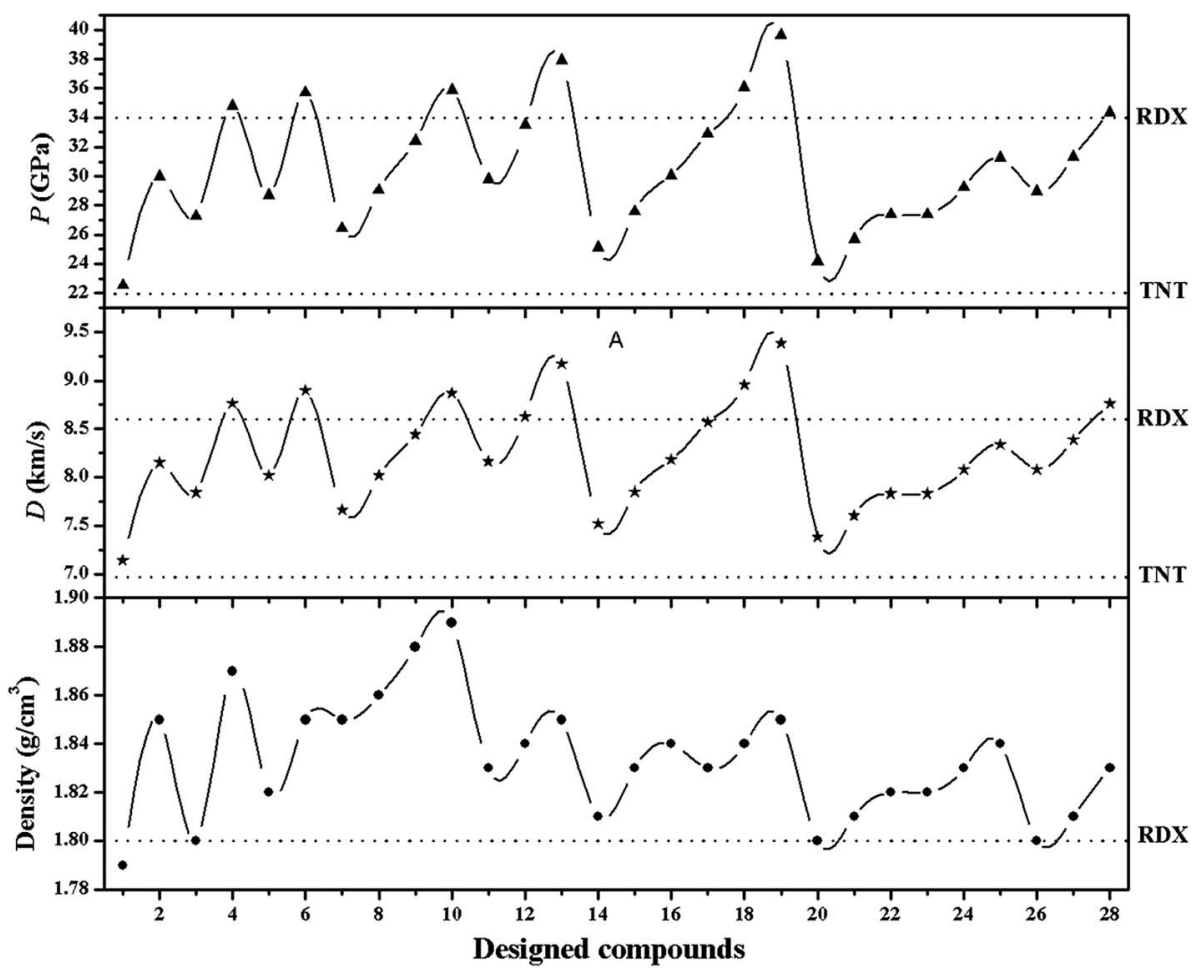

Fig. 2 Correlation between density, detonation velocity $(D)$, and pressure $(P)$ of the peracid compounds and their comparison with those of TNT and RDX.

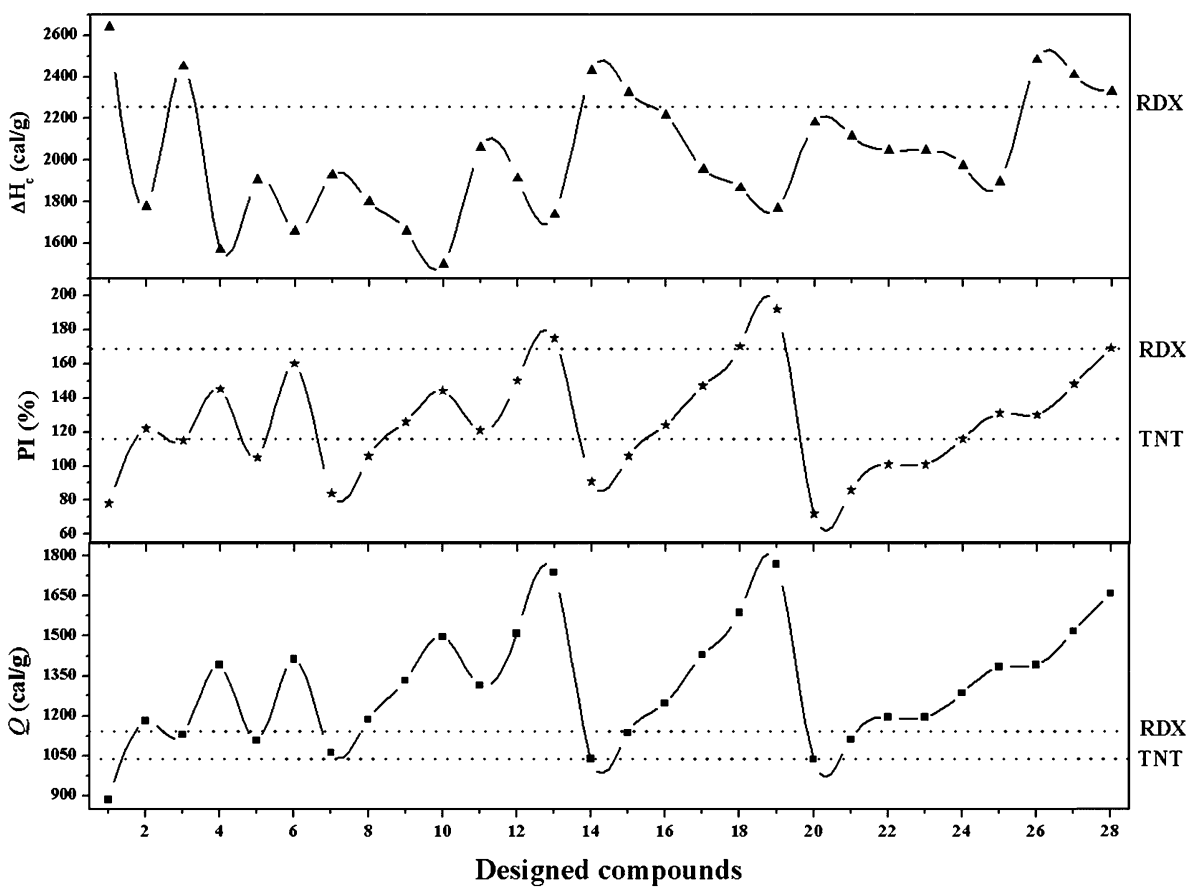

Fig. 3 The heat of detonation $(Q)$, power index $(\mathrm{PI})$, and the heat of explosion $\left(\Delta H_{\mathrm{e}}\right)$ of the peracid compounds.

rich framework is an efficient way to reduce sensitivity without losing too much performance. However, further studies are required to understand the influence of $\pi$ conjugated system on the stability of the framework.

\section{Conclusions}

In this study, 20 peracid-substituted nitrogen-rich compounds were designed, and their energetic properties were investigated 
using computational methods. Most of the peracid compounds showed comparable/higher density (in the range of 1.79-1.88 g $\mathrm{cm}^{-3}$ ) than TNT and RDX. In addition, these compounds exhibited good energetic properties (detonation velocity 7.14$8.96 \mathrm{~km} \mathrm{~s}^{-1}$, detonation pressure 22.5-36.0 GPa, power index 78-170\%, brisance 96-142, and Gurney velocity $2.38-2.96 \mathrm{~km}$ $\mathrm{s}^{-1}$ ) that surpassed those of TNT. Moreover, heat of detonation was used as the measure of sensitivity, and most of these compounds exhibited acceptable sensitive behavior. The good energetic properties imply the explosophoric nature of the peracid group and suggest its potential in designing new energetic materials.

\section{Acknowledgements}

This work was supported by the grant received from DST-SERB, Government of India (Young Scientists, No. SB/FT/CS-110/ 2014). Alka Devi would like to thank CSIR for research fellowship (No. 09/1050(0005) 2015-EMR-1).

\section{References}

1 H. Gao and J. M. Shreeve, Chem. Rev., 2011, 111, 7377-7436. 2 R. D. Chapman, W. S. Wilson, J. W. Fronabarger, L. H. Merwin and G. S. Ostrom, Thermochim. Acta, 2002, 384, 229-243.

3 P. F. Pagoria, G. S. Lee, A. R. Mitchell and R. D. Schmidt, Thermochim. Acta, 2002, 384, 187-204.

4 A. K. Sikder and N. Sikder, J. Hazard. Mater., 2004, 112, 1-15.

5 D. M. Badgujar, M. B. Talawar, S. N. Asthana and P. P. Mahulikar, J. Hazard. Mater., 2008, 151, 289-305.

6 T. M. Klapötke, High Energy Density Materials, Springer, Berlin, Heidelberg, 2007.

7 H. G. Ang and S. Pisharath, Energetic Polymers, Wiley-VCH Verlag \& Co. KGaA, Weinheim, Germany, 2012.

8 J. Zhang, D. Srinivas, L. A. Mitchell, D. A. Parrish and J. M. Shreeve, J. Am. Chem. Soc., 2016, 138, 7500-7503.

9 D. Srinivas, L. A. Mitchell, D. A. Parrish and J. M. Shreeve, Chem. Commun., 2016, 52, 7668-7671.

10 M. H. Keshavarz, J. Hazard. Mater., 2007, 143, 437-442.

11 M. H. Keshavarz, H. Motamedoshariati, R. Moghayadnia, M. Ghanbarzadeh and J. Azarniamehraban, Propellants, Explos., Pyrotech., 2013, 38, 95-102.

12 G. X. Wang, C. H. Shi, X. D. Gong and H. M. Xiao, J. Phys. Chem. A, 2009, 113, 1318-1326.

13 P. Politzer, J. S. Murray, J. M. Seminario, P. Lane, M. E. Grice and M. C. Concha, J. Mol. Struct.: THEOCHEM, 2001, 573, 110.

14 T. M. Klapötke, Chemistry of High-Energy Materials, Walter de Gruyter GmbH \& Co. KG, Berlin, New York, 2011.

15 N. D. H. Gamage, B. Stiasny, J. Stierstorfer, P. D. Martin, T. M. Klapötke and C. H. Winter, Chem.-Eur. J., 2016, 22, 2582-2585.

16 N. D. H. Gamage, B. Stiasny, E. G. Kratz, J. Stierstorfer, P. D. Martin, G. A. Cisneros, T. M. Klapötke and C. H. Winter, Eur. J. Inorg. Chem., 2016, 5036-5043.
17 M. H. V. Huynh, M. A. Hiskey, C. J. Pollard, D. P. Montoya, E. L. Hartline and R. Gilardi, J. Energ. Mater., 2004, 22, 217-229.

18 D. E. Chavez, M. A. Hiskey and D. L. Naud, Propellants, Explos., Pyrotech., 2004, 29, 209-215.

19 V. Thottempudi, H. Gao and J. M. Shreeve, J. Am. Chem. Soc., 2011, 133, 6464-6471.

20 C. Qi, R. Zhang and S. P. Pang, RSC Adv., 2013, 3, 1774117748.

21 X. Zhao, C. Qi, R. Zhang, S. Zhang, S. Li and S. Pang, J. Mol. Model., 2015, 21, 223.

22 T. M. Klapötke and D. G. Piercey, Inorg. Chem., 2011, 50, 2732-2734.

23 M. J. Frisch, G. W. Trucks, H. B. Schlegel, G. E. Scuseria, M. A. Robb, J. R. Cheeseman, G. Scalmani, V. Barone, G. A. Petersson, H. Nakatsuji, X. Li, M. Caricato, A. Marenich, J. Bloino, B. G. Janesko, R. Gomperts, B. Mennucci, H. P. Hratchian, J. V. Ortiz, A. F. Izmaylov, J. L. Sonnenberg, D. Williams-Young, F. Ding, F. Lipparini, F. Egidi, J. Goings, B. Peng, A. Petrone, T. Henderson, D. Ranasinghe, V. G. Zakrzewski, J. Gao, N. Rega, G. Zheng, W. Liang, M. Hada, M. Ehara, K. Toyota, R. Fukuda, J. Hasegawa, M. Ishida, T. Nakajima, Y. Honda, O. Kitao, H. Nakai, T. Vreven, K. Throssell, J. A. Montgomery Jr, J. E. Peralta, F. Ogliaro, M. Bearpark, J. J. Heyd, E. Brothers, K. N. Kudin, V. N. Staroverov, T. Keith, R. Kobayashi, J. Normand, K. Raghavachari, A. Rendell, J. C. Burant, S. S. Iyengar, J. Tomasi, M. Cossi, J. M. Millam, M. Klene, C. Adamo, R. Cammi, J. W. Ochterski, R. L. Martin, K. Morokuma, O. Farkas, J. B. Foresman and D. J. Fox, Gaussian 09, Revision E.01, Gaussian, Inc., Wallingford, CT, 2013.

24 T. Lu and F. Chen, J. Comput. Chem., 2012, 33, 580-592.

25 V. D. Ghule, J. Phys. Chem. A, 2012, 116, 9391-9397.

26 S. Deswal, V. D. Ghule, T. Ram Kumar and S. Radhakrishnan, Comput. Theor. Chem., 2015, 1054, 55-62. 27 A. Devi, S. Deswal, D. Srinivas and V. D. Ghule, J. Mol. Model., 2015, 21, 298.

28 V. D. Ghule, S. Deswal, A. Devi and T. Ram Kumar, Ind. Eng. Chem. Res., 2016, 55, 875-881.

29 A. Devi and V. D. Ghule, Can. J. Chem., 2016, 94, 738-743.

30 R. Haiges, G. Bélanger-Chabot, S. M. Kaplan and K. O. Christe, Dalton Trans., 2015, 44, 7586-7594.

31 P. Ravi, S. K. Shee, G. M. Gore, S. P. Tewari and A. K. Sikder, Struct. Chem., 2011, 22, 661-669.

32 M. A. M. Rashid, S. G. Cho, T. H. Choi and C. H. Choi, Theor. Chem. Acc., 2015, 134, 126.

33 P. Ravi and S. P. Tewari, Struct. Chem., 2012, 23, 487-498. 34 T. Wei, W. H. Zhu, X. W. Zhang, Y. F. Li and H. M. Xiao, J. Phys. Chem. A, 2009, 113, 9404-9412.

35 Q. Wu, W. Zhu and H. M. Xiao, J. Chem. Eng. Data, 2013, 58, 2748-2762.

36 L. Türker, T. Atalar, S. Gümüş and Y. Çamur, J. Hazard. Mater., 2009, 167, 440-448.

37 W. H. Zhu, C. C. Zhang, T. Wei and H. M. Xiao, J. Comput. Chem., 2011, 32, 2298-2312.

38 Y. Pan, W. H. Zhu and H. M. Xiao, J. Mol. Model., 2012, 18, 3125-3138. 
39 D. L. Naud, M. A. Hiskey and H. H. Harry, J. Energ. Mater., 2003, 21, 57-62.

40 C. L. Mader, in Organic Energetic Compounds, ed. P. L. Markinas, Nova Science Publishers, Commack, New York, 1996.

41 C. Ye and J. M. Shreeve, J. Chem. Eng. Data, 2008, 53, 520524.

42 B. M. Rice and D. M. Sorescu, J. Phys. Chem. B, 2004, 108, 17730-17739.

43 P. Politzer and J. S. Murray, Cent. Eur. J. Energ. Mater., 2014, 11, 459-474.
44 P. Politzer, J. Martinez, J. S. Murray, M. C. Concha and A. Toro-Labbé, Mol. Phys., 2009, 107, 2095-2101.

45 M. H. Keshavarz, F. Seif and H. Soury, Propellants, Explos., Pyrotech., 2014, 39, 284-288.

46 R. W. Gurney, The Initial Velocities of Fragments from Bombs, Shells and Grenades, Ballistic Research Laboratories, Aberdeen, Maryland, BRL Report No. 405, 1943.

47 M. J. Kamlet and M. Finger, Combust. Flame, 1979, 34, 213214.

48 D. R. Hardesty and J. E. Kennedy, Combust. Flame, 1977, 28, 45-59.

49 P. Politzer and J. S. Murray, J. Mol. Model., 2015, 21, 262. 